\title{
Molecular Support for the Hybrid Origin of the Wild Potato Species Solanum $\times$ rechei
}

\author{
A. M. Clausen* and D. M. Spooner
}

\begin{abstract}
Twenty-seven of the 232 wild potato species (Solanum sect. Petota) have been hypothesized to be of natural hybrid origin. Prior molecular data have failed to support hybrid origins involving two other wild potato species, Solanum raphanifolium Cárdenas and Hawkes and $S$. chacoense Bitter, and hybrid speciation has never been supported with molecular data in sect. Petota. This study was conducted to test the hybrid origin of Solanum $\times$ rechei Hawkes and Hjert. It is a locally common and weedy wild potato species from Argentina, occurring at the extreme southern end of the range of S. microdontum Wittm., and near the northern end of the range of S. kurtzianum Bitter, its two putative parents. Solanum $\times$ rechei is diploid $(2 n=2 x=24)$ with triploid $(2 n=3 x=36)$ populations, $S$. kurtzianum is diploid $(2 n=2 x=24)$, and $S$. microdontum is diploid $(2 n=2 x=24)$, with triploid populations at its extreme southern range. A prior study supported the hybrid origin of $S . \times$ rechei by intermediate morphology of natural and synthetic hybrids, reduced pollen stainability of the natural and synthetic hybrids, and distributional evidence. Our studies of new collections and prior germplasm collections fail to support the morphological intermediacy of $S . \times$ rechei, but lack of morphological intermediacy is common for many hybrids. Hybrid origin was instead verified by reduced pollen stainability and additive parent-specific single- to low-copy nuclear restriction fragment length polymorphisms (RFLPs) in $S . \times$ rechei. These data suggest that other wild potato species also may be of hybrid origin, which may help explain some of the taxonomic confusion in the group.
\end{abstract}

$S$ OLANUm L. sect. Petota Dumort., the potato and its wild relatives, contains seven cultivated and 225 wild species, according to the latest taxonomic interpretation (Hawkes, 1990). An alternative classification (Child, 1990), supported by morphological and chloroplast DNA (cpDNA) data (Spooner et al., 1993), classifies all of the tuber-bearing species in sect. Petota, and the nontuber-bearing species in sect. Etuberosum $(\mathrm{Bu}-$ kasov and Kameraz) A. Child, sect. Juglandifolium (Rydb.) A. Child, and sect. Lycopersicum (Mill.) Wettst. Hawkes (1990) classifies the 223 tuber-bearing species into 19 series, distributed from the southwestern USA to southern Chile, with a concentration of diversity in the Andes.

While well-developed crossing barriers prevent hybridization between some species (Johnston and Hanneman, 1980, 1982; Hanneman, 1994), many others are freely able to hybridize naturally and artificially (Hawkes, 1978, 1990; Hawkes and Hjerting, 1969, 1989; Johnston and Hanneman, 1980; Ochoa, 1990). Natural interspecific hybridization has been hypothesized to be common in sect. Petota (sensu Child, 1990). There are 27 diploid or polyploid taxa of putative hybrid origin in the group, involving both wild and cultivated species

A.M. Clausen, Estación Experimental Agropecuaria, Instituto Nacional de Tecnología Agropecuaria (INTA), C.C. 276, 7620 Balcarce, Argentina; and D.M. Spooner, Vegetable Crops Research Unit, USDA-ARS, Dep. of Horticulture, 1575 Linden Dr., Univ. of Wisconsin, Madison, WI 53706-1590, USA Received 29 May 1997. *Corresponding author (dspooner@facstaff.wisc.edu).

Published in Crop Sci. 38:858-865 (1998).
(Spooner and van den Berg, 1992). Eleven of the putative hybrids are diploid, six triploid, three tetraploid, three pentaploid, and four hexaploid. Five of the seven cultivated species and 22 of the wild species accepted by Hawkes (1990) are of putative hybrid origin.

Many of these hybridization hypotheses have been generated from intuitive methods involving intermediate morphology and inference from distributional data (Hawkes, 1963, 1990). Others have been supported by artificial reconstruction of the putative hybrids (Okada and Clausen, 1982; Okada and Hawkes, 1978), additivity of flavonoids and/or tuber proteins (Cribb and Hawkes, 1986; Rickeman and Desborough, 1978), and by cytogenetic data (Matsubayashi, 1991).

Solanum $\times$ rechei Hawkes and Hjert. is one of the better documented hybrids. It is endemic to the eastern slopes of the Sierra de Famatina in Argentina, Province of La Rioja, Department of Chilecito. Eight populations are scattered over a distance of $12 \mathrm{~km}$, with populations containing hundreds of individuals (Okada and Hawkes, 1978; Spooner and Clausen, 1993). Within this region, $S$. $\times$ rechei is common and weedy, growing along roadsides in ditches and open fields, or under trees in orchards. The species was first collected in 1928, and has been persistent for at least $69 \mathrm{yr}$.

Solanum $\times$ rechei was first described as a distinct species, and was hypothesized to be ancestral to $S$. maglia Schltdl. (Hawkes, 1963). Subsequent field studies by Hawkes and Hjerting (1969) suggested that $S . \times$ rechei was of hybrid origin between $S$. kurtzianum Bitter and S. microdontum Wittm., with introgression from $S$. spegazzinii Bitter.

Solanum $\times$ rechei is narrowly restricted to the overlap zone of $S$. kurtzianum and $S$. microdontum. It grows near the northern end of the range of $S$. kurtzianum, and at the extreme southern end of the range of $S$. microdontum (Fig. 1). All known populations of $S$. microdontum are diploid $(2 n=2 x=24)$, except for the presence of triploid $(2 n=3 x=36)$ populations in the extreme southern end of its range (Okada, 1981). All known populations of $S$. kurtzianum are diploid $(2 n=$ $2 x=24$ ) (Hawkes and Hjerting, 1989; Hawkes, 1990). Solanum microdontum, $S$. $\times$ rechei, and $S$. kurtzianum are the only wild potato species recorded from the Department of Chilecito where $S$. $\times$ rechei grows. The closest other wild potato species are $S$. acaule Bitter ssp. acaule, S. acaule ssp. aemulans (Bitter and Wittm.) Hawkes and Hjert., S. chacoense Bitter, and S. spegazzinii, found in the Province of La Rioja in the Departments of Capital, Famatina, and Sanagasta, at least 20 km away by air (Hawkes and Hjerting, 1969; Okada and Hawkes, 1978).

Abbreviations: BAL, Herbarium of the Instituto Nacional de Tecnología Agropecuaria (INTA), in Balcarce, Argentina; PCA, Principal Components Analysis; PTIS, Herbarium of the Potato Introduction Station of NRSP-6; NRSP-6, National Research Program-6, the USA Potato Genebank at Sturgeon Bay, WI. 


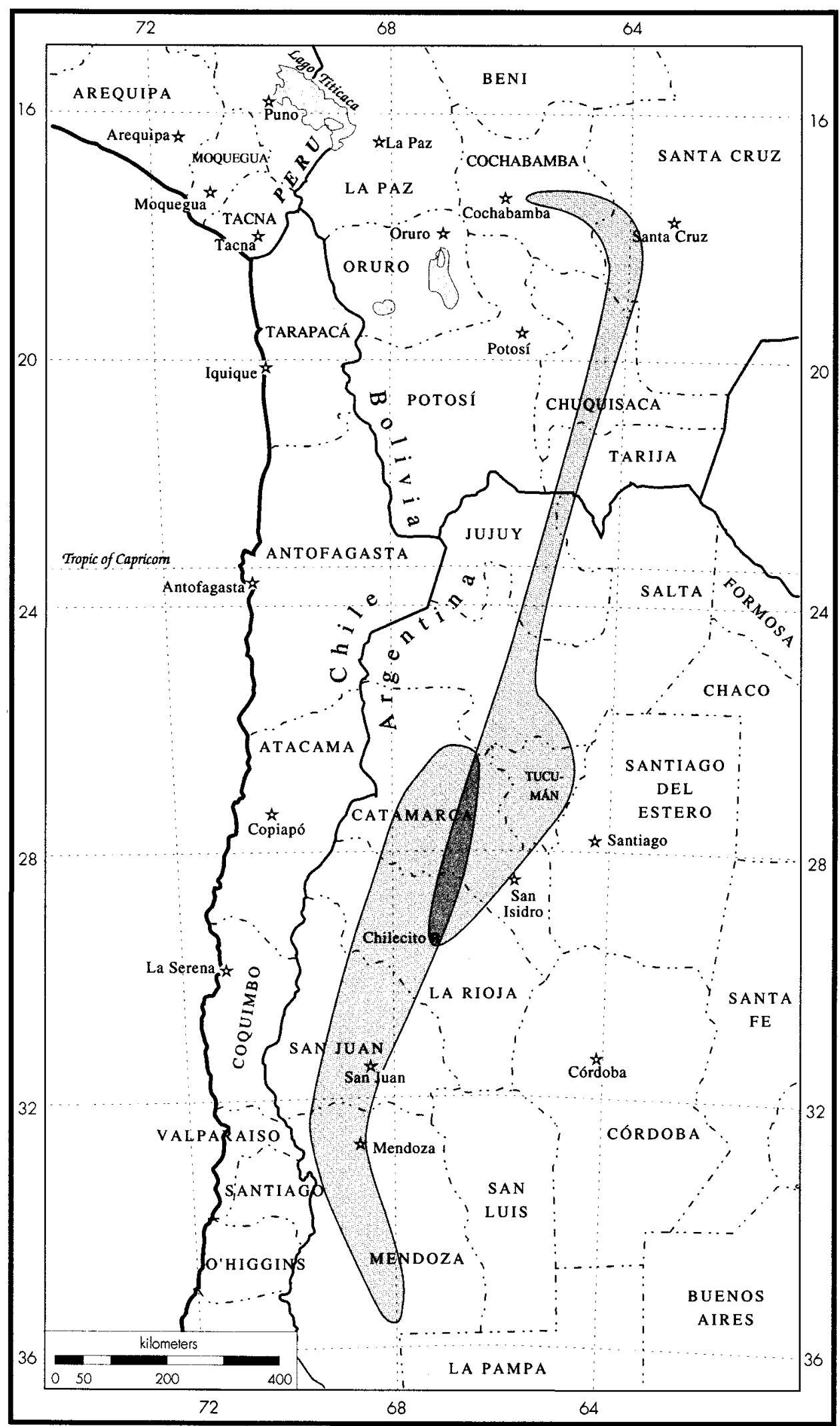

Fig. 1. D istribution of Solanum microdontum (shaded area north, B olivia and A rgentina), S. kurtzianum (shaded area south, A rgentina), overlap zone of both species (darker shade), and of $S . \times$ rechei (area of $R$, showing approximate area of distribution, at southern end of range of S. microdontum ). 
The hybrid origin of $S . \times$ rechei was tested by field studies, reciprocal synthetic reconstructions of the hybrid, analyses of morphological characters, chromosome counts, and pollen stainability (Okada and Hawkes, 1978). These authors made the following conclusions: (i) all of the natural populations of S. microdontum from the area of sympatry were triploid $(2 n=36)$ with low male fertility $(0-14 \%$ pollen stainability), (ii) all of the natural populations of $S$. kurtzianum were diploid, with high male fertility (78-99\% pollen stainability), (iii) all natural populations of $S . \times$ rechei were diploid, except for one population that had both diploid and triploid individuals, and male fertility ranged from 2 to $88 \%$ pollen stainability, (iv) natural populations of $S . \times$ rechei produced numerous tubers and apparently reproduced vigorously by tubers, (v) Solanum $\times$ rechei was of hybrid origin between triploid populations of S. microdontum as females and diploid populations of $S$. kurtzianum as males, and (vi) Solanum spegazzinii was not involved in the origin of $S . \times$ rechei.

Synthetic hybridizations of these species by Okada and Hawkes (1978), using triploid S. microdontum as the female parent, produced $\mathrm{F}_{1}$ individuals with diploid $(2 n=24)$ and aneuploid $(2 n=25-31,37)$ levels, but the aneuploids exhibited reduced viability in the field relative to the diploids. Although Hawkes (1990) stated that $S$. $\times$ rechei was of hybrid origin between $S$. microdontum and $S$. kurtzianum, he also stated that it was exclusively triploid, and had possible introgression from S. spegazzinii. This conflicted with his latest publication on $S$. $\times$ rechei (Okada and Hawkes, 1978) that concluded that all but one population of $S . \times$ rechei was diploid, and that $S$. spegazzinii was not an additional parent.

Brücher (1989) conducted field studies of $S . \times$ rechei and noted their extensive morphological variability, weediness, and locally common occurrence. He interpreted these phenomena to be caused by advanced generation segregants of $S$. kurtzianum $\times S$. microdontum, naturally dispersed by agricultural activities. He thought that $S$. $\times$ rechei should not be given a separate species name.

Our study clarifies the hybrid origin of $S . \times$ rechei by field studies, morphological analyses, pollen stainability of new collections and prior germplasm collections, and studies of single- to low-copy nuclear RFLPs (nRFLPs).

\section{MATERIALS AND METHODS}

\section{Plant Material}

Seeds or tubers from 13 accessions of S. kurtzianum, six of $S$. $\times$ rechei, and six of $S$. microdontum were collected on a recent expedition to Argentina (Spooner and Clausen, 1993), or were obtained from germplasm accessions at the Potato Germplasm Bank of the Instituto Nacional de Tecnología Agropecuaria, Balcarce, Argentina (Okada, 1974), and the National Research Support Program-6 in Sturgeon Bay, WI (NRSP-6, Bamberg et al., 1996) (Table 1). Vouchers are deposited at the herbaria of BAL and PTIS (Holmgren et al., 1990; Bamberg and Spooner, 1994). Plants used in the molecular study (Table 1) were largely a subset of those used in the morphological study, with the addition of other diploid $(2 n=$ 24) tuber-bearing species of sect. Petota: S. berthaultii (ser. Tuberosa [Rydb.] Hawkes), S. chacoense (ser. Yungasensia Correll), S. commersonii (ser. Commersoniana Buk.), S. tarijense (ser. Yungasensia), and S. palustre (sect. Etuberosum). Solanum microdontum, $S . \times$ rechei, and S. kurtzianum are all in ser. Tuberosa (series affiliations follow Hawkes, 1990). These additional species were chosen to compare the genetic diversity of the hybrid study group to other species in sect. Petota and the related sect. Etuberosum.

\section{Morphology and Pollen Stainability}

All morphological measurements were from plants grown under uniform conditions in a screenhouse in Balcarce, Argentina. Twenty-two characters (18 quantitative and four qualitative) were measured from seven plants per accession in January 1991, after flowering had commenced. Measurements of leaves were made on the fifth true leaf from the base of the plant. Traits were numbered as follows, in which Traits 1 to 13 were vegetative, Traits 14 to 19 were floral, and Traits 20 to 22 were reproductive: 1 , height of plant $(\mathrm{cm}) ; 2$, color of stem: green (1), green with purple spots or purple mottled (2), purple with green spots or green mottled (3), purple (4); 3 , width of stem wing $(\mathrm{mm}) ; 4$, length of leaf $(\mathrm{cm}) ; 5$, width of leaf $(\mathrm{cm}) ; 6$, number of pairs of lateral leaflets; 7 , length of terminal leaflet $(\mathrm{cm}) ; 8$, width of terminal leaflet $(\mathrm{cm}) ; 9$, length of distal most lateral leaflet $(\mathrm{cm}) ; 10$, width of distal most lateral leaflet $(\mathrm{cm}) ; 11$, length of second distal most lateral leaflet $(\mathrm{cm}) ; 12$, width of second distal most lateral leaflet $(\mathrm{cm}) ; 13$, number of interjected leaflets; 14, position of pedicel articulation: below middle (1), at middle (2); above middle (3); 15, length of calyx $(\mathrm{mm}) ; 16$, color of adaxial surface of corolla: white (1), white with purple acumens (2), white with light purple stripes radiating from center of corolla to apex of corolla lobes, "star," (3), white with dark purple star (4); 17, ratio: radius from center of corolla to base of corolla lobe/radius of corolla (see illustration in Spooner and van den Berg, 1992); 18, length of anther (mm); 19, exsertion of style from apex of anthers $(\mathrm{mm}) ; 20$, anther formation: deformed (0), deformed and normal on same plant (1), all normal (2); 21, pollen production: greatly reduced (1), normal (2); 22, percent pollen stainability.

Pollen fertility of $S$. microdontum, $S$. $\times$ rechei, and $S$. kurtzianum was estimated by staining pollen in acetocarmine. Pollen was collected from at least four flowers from at least four separate plants per accession and mixed together on the same slide with stain. This single count was taken as representative of the accession. Only fully formed and darkly stained grains were scored as stained.

To test for morphological intermediacy, we analyzed the data by principal components analysis (PCA). This was accomplished with product-moment correlations and eigenvectors. We used the standardized means of seven plants per accession as character scores, using computer programs in NTSYS-pc, version 1.70 (Rohlf, 1992). These analyses were performed for all characters, and then for all characters except for reproductive characters 20 through 22 .

In addition to PCA, we used the univariate "charactercount procedure" suggested by Wilson (1992) and later applied by Thébaud and Abbott (1995) and Miller and Spooner (1996). Wilson (1992) argued, on the basis of computer simulations, that hybridity based on morphological data could only be distinguished from divergence by tabulating intermediate and non-intermediate character states, followed by a onesided sign test (Zar, 1984). 
Table 1. Wild potato species examined for DNA and morphological characteristics.

\begin{tabular}{|c|c|c|c|c|}
\hline Taxon & Analysis $\dagger$ & PI (BAL) $\ddagger$ & $\begin{array}{l}\text { Collector and } \\
\text { collection number }\end{array}$ & Locality§ \\
\hline Solanum berthaultii & D & 498107 & Hawkes et al. $6556 \mathrm{~B}$ & Bolivia. Cochabamba: Hacienda Mollepujro, $17^{\circ} 57^{\prime} \mathrm{S}, 65^{\circ} 55^{\prime} \mathrm{W}$. \\
\hline S. palustreף & D & 245764 & Correll C.15 & Chile: Region Araucanía: Pucón, $39^{\circ} 16^{\prime} \mathrm{S}, 7^{\circ} \mathbf{5 3}^{\prime} \mathrm{W}$. \\
\hline S. commersonii & D & 243503 & Fernandez s. $n$. & Argentina. Buenos Aires: near Buenos Aires, $31^{\circ} 46^{\prime} \mathrm{S}, 60^{\circ} 32^{\prime} \mathrm{W}$. \\
\hline S. chacoense & D & 217451 & Sleumer 3566 & Argentina. Jujuy: Tumbaya, $23^{\circ} 55^{\prime} \mathrm{S}, 65^{\circ} 25^{\prime} \mathrm{W}$. \\
\hline \multirow[t]{15}{*}{ S. kurtzianum } & $\mathbf{D}, \mathbf{M}$ & (90029) & Spooner and Clausen 4544 & Argentina. Mendoza: Las Heras, $680 \mathrm{~m}, 3^{\circ} 33^{\prime} \mathrm{S}, 68^{\circ} 58^{\prime} \mathrm{W}$. \\
\hline & $\mathbf{D}, \mathbf{M}$ & (90033) & Spooner and Clausen 4548 & Argentina. Mendoza: Las Heras, $1600 \mathrm{~m}, 32^{\circ} 26^{\prime} \mathrm{S}, 68^{\circ} 56^{\prime} \mathrm{W}$. \\
\hline & $\mathbf{M}$ & (90005) & Spooner and Clausen 4505 & Argentina. Mendoza: Las Heras, $1185 \mathrm{~m}, 3^{\circ} 24^{\prime} \mathrm{S}, 68^{\circ} 52^{\prime} \mathrm{W}$. \\
\hline & $\mathbf{M}$ & (90034) & Spooner and Clausen 4549 & Argentina. Mendoza: Las Heras, $1660 \mathrm{~m}, 32^{\circ} 25^{\prime} \mathrm{S}, 68^{\circ} 57^{\prime} \mathrm{W}$. \\
\hline & $\mathbf{M}$ & (90033) & Spooner and Clausen 4550 & Argentina. Mendoza: Las Heras, $1600 \mathrm{~m}, 3^{\circ} 26^{\prime} \mathrm{S}, 68^{\circ} 58^{\prime} \mathrm{W}$. \\
\hline & $\mathbf{D}, \mathbf{M}$ & (90037) & Spooner and Clausen 4552 & Argentina. Mendoza: Las Heras, $2330 \mathrm{~m}, \mathbf{3 2}^{\circ} 32^{\prime} \mathrm{S}, \mathbf{6 9}^{\circ} 02^{\prime} \mathrm{W}$. \\
\hline & M & (90044) & Spooner and Clausen 4568 & Argentina. La Rioja: Chilecito, $1800 \mathrm{~m}, 2^{\circ} 15^{\prime} \mathrm{S}, 6^{\circ} 39^{\prime} \mathrm{W}$. \\
\hline & & $558203(90045)$ & Spooner and Clausen 4570 & Argentina. La Rioja: Chilecito, $1760 \mathrm{~m}, 2^{\circ} 15^{\prime} \mathrm{S}, 67^{\circ} 40^{\prime} \mathrm{W}$. \\
\hline & $\mathbf{D}, \mathbf{M}$ & (90048) & Spooner and Clausen 4573 & Argentina. La Rioja: Chilecito, $1880 \mathrm{~m}, 2^{\circ} 12^{\prime} \mathrm{S}, 67^{\circ} 39^{\prime} \mathrm{W}$. \\
\hline & $\mathbf{D}, \mathbf{M}$ & (90050) & Spooner and Clausen 4575 & Argentina. La Rioja: Chilecito, $1670 \mathrm{~m}, 2^{\circ} 12^{\prime} \mathrm{S}, 67^{\circ} 38^{\prime} \mathrm{W}$. \\
\hline & $\mathbf{D}, \mathbf{M}$ & $558207(90051)$ & Spooner and Clausen 4576 & Argentina. La Rioja: Chilecito, $1880 \mathrm{~m}, 2^{\circ} 11^{\prime} \mathrm{S}, 67^{\circ} 38^{\prime} \mathrm{W}$. \\
\hline & $\mathbf{M}$ & (90052) & Spooner and Clausen $4577 B$ & Argentina. La Rioja: Chilecito, $1790 \mathrm{~m}, 2^{\circ} 10^{\prime} \mathrm{S}, 67^{\circ} 39^{\prime} \mathrm{W}$. \\
\hline & $\mathbf{D}, \mathbf{M}$ & $558208(90053)$ & Spooner and Clausen 4578 & Argentina. La Rioja: Chilecito, $1790 \mathrm{~m}, 29^{\circ} 10^{\prime} \mathrm{S}, 67^{\circ} 39^{\prime} \mathrm{W}$. \\
\hline & & 320271 & Hawkes and Hjerting 613 & Argentina. Catamarca: Santa Rosa, $28^{\circ} 10^{\prime} \mathrm{S}, 65^{\circ} 30^{\prime} \mathrm{W}$. \\
\hline & D & 442679 (72087) & Okada 4285 & Argentina. San Juan: Iglesia, $2700 \mathrm{~m}, 30^{\circ} 22^{\prime} \mathrm{S}, 6^{\circ} 35^{\prime} \mathrm{W}$. \\
\hline \multirow{9}{*}{ S. microdontum } & M & (74481) & Okada 5902 & Argentina. Salta: Santa Victoria, $2900 \mathrm{~m}, 2^{\circ} 08^{\prime} \mathrm{S}, 6^{\circ} 02^{\prime} \mathrm{W}$. \\
\hline & $\mathbf{M}$ & 473171 (74265) & Okada 5623 & Argentina. Salta: Chicoana, $1720 \mathrm{~m}, 25^{\circ} 09^{\prime} \mathrm{S}, 65^{\circ} 41^{\prime} \mathrm{W}$. \\
\hline & $\mathbf{M}$ & 473179 (76138) & Okada 6326 & Argentina. Salta: Santa Victoria, $3000 \mathrm{~m}, 22^{\circ} 20^{\prime} \mathrm{S}, 65^{\circ} 02^{\prime} \mathrm{W}$. \\
\hline & $\mathbf{M}$ & 473180 (76139) & Okada 6327 & Argentina. Salta: Santa Victoria, $3000 \mathrm{~m}, 22^{\circ} 20^{\prime} \mathrm{S}, 65^{\circ} 02^{\prime} \mathrm{W}$. \\
\hline & D & (90074) & Spooner and Clausen & Argentina. Catamarca: Andalgalá, $2000 \mathrm{~m}, 27^{\circ} 21^{\prime} \mathrm{S}, 66^{\circ} 00^{\prime} \mathrm{W}$. \\
\hline & $\mathbf{D}, \mathbf{M}$ & $565075(90084)$ & Spooner and Clausen 4631 & Argentina. Catamarca: Andalgalá, $2030 \mathrm{~m}, 27^{\circ} 19^{\prime} \mathrm{S}, 66^{\circ} 39^{\prime} \mathrm{W}$. \\
\hline & $\mathbf{D}, \mathbf{M}$ & 558218 (90082) & Spooner and Clausen 4632 & Argentina: Catamarca: Andalgalá, $2030 \mathrm{~m}, 27^{\circ} 19^{\prime} \mathrm{S}, 66^{\circ} 03^{\prime} \mathrm{W}$. \\
\hline & D & 458356 (72270) & Okada 4478 & Argentina. Salta: Oran, $3000 \mathrm{~m}, \mathbf{2 3}^{\circ} 13^{\prime} \mathrm{S}, \mathbf{6 4}^{\circ} 55^{\prime} \mathrm{W}$. \\
\hline & D & 310979 & Alandia 64-11 & Bolivia. \\
\hline \multirow{7}{*}{ S. $\times$ rechei } & $\mathbf{D}, \mathbf{M}$ & (90047) & Spooner and Clausen 4572 & Argentina. La Rioja: Chilecito, $1820 \mathrm{~m}, 2^{\circ} 13^{\prime} \mathrm{S}, 6^{\circ} 39^{\prime} \mathrm{W}$. \\
\hline & $\mathbf{D}, \mathbf{M}$ & (90049) & Spooner and Clausen 4574 & Argentina. La Rioja: Chilecito, $1880 \mathrm{~m}, 2^{\circ} 12^{\prime} \mathrm{S}, 67^{\circ} 39^{\prime} \mathrm{W}$. \\
\hline & $\mathbf{D}, \mathbf{M}$ & $558229(90052)$ & Spooner and Clausen 4577A & Argentina. La Rioja: Chilecito, $1970 \mathrm{~m}, 2^{\circ} 10^{\prime} \mathrm{S}, 67^{\circ} 39^{\prime} \mathrm{W}$. \\
\hline & $\mathbf{D}, \mathbf{M}$ & $587112(90054)$ & Spooner and Clausen 4579 & Argentina. La Rioja: Chilecito, $1820 \mathrm{~m}, 2^{\circ} 09^{\prime} \mathrm{S}, 67^{\circ} 40^{\prime} \mathrm{W}$. \\
\hline & $\mathbf{M}$ & 558231 (90055) & Spooner and Clausen 4581 & Argentina. La Rioja: Chilecito, $1840 \mathrm{~m}, 2^{\circ} 09^{\prime} \mathrm{S}, 67^{\circ} 40^{\prime} \mathrm{W}$. \\
\hline & $\mathbf{D}, \mathbf{M}$ & 587113 (90067) & Spooner and Clausen 4583 & Argentina. La Rioja: Chlecito, $1520 \mathrm{~m}, 2^{\circ} 08^{\prime} \mathrm{S}, 67^{\circ} 37^{\prime} \mathrm{W}$. \\
\hline & & 458364 (71281) & Hoffmann 1876 & Argentina. Salta: Santa Victoria, $2200 \mathrm{~m}, 22^{\circ} 15^{\prime} \mathrm{S}, 64^{\circ} 58^{\prime} \mathrm{W}$. \\
\hline
\end{tabular}

$\dagger \mathbf{D}=$ Accession analyzed for DNA characteristics; $\mathbf{M}=$ accession analyzed for morphological characteristics.

$\$$ Number in parentheses $=$ Balcarce, Argentina genebank number. The accessions lacking PI numbers are in the process of being increased and are later to be made available from the United States potato genebank.

$\S$ Country, Province (Argentina and Bolivia) or Region (Chile).

II Solanum palustre was previously known as $\boldsymbol{S}$. brevidens (Contreras and Spooner, in press).

\section{Chromosome Counts}

Mitotic chromosome counts were made from root tips gathered from sprouting tubers placed in moist sphagnum. Root tips were fixed for $6 \mathrm{~h}$ in $3: 1100 \%(\mathrm{v} / \mathrm{v})$ ethanol/glacial acetic acid, hydrolyzed for $10 \mathrm{~min}$ in $1 \mathrm{M} \mathrm{HCl}$ heated to $65^{\circ} \mathrm{C}$, and squashed in hematoxylin fixative with added iron mordant (Sharma and Sharma, 1956).

\section{Nuclear RFLPs}

A random genomic library from the wild potato Solanum phureja Juz. et Buk. was used (P clones) as described by Hosaka and Spooner (1992). Also, one homologous TG clone from tomato (Tanksley et al., 1992) was used, for a total of 15 clones (P60, P122, P135, P209, P256, P279, P298, P307, P380, P392, P398, P473, P480, P925, TG23). The clones were amplified by polymerase chain reaction and radiolabeled with ${ }^{32} \mathrm{P}$-dCTP by the method of Feinberg and Vogelstein (1984).

DNA was isolated from $3 \mathrm{~g}$ fresh leaf tissue or $1 \mathrm{~g}$ freezedried tissue, from bulked leaves of three to five plants per accession. Plants were bulked for DNA extraction in order to discover additional putative alleles within the accessions. All isolation and purification protocols followed those in Giannattasio and Spooner (1994), except that $6 \times$ CTAB was substituted for $2 \times$ CTAB (Smith et al., 1991), and all DNA was further purified over $\mathrm{CsCl}$ gradients. Five micrograms of each DNA sample were digested with DraI, EcoRI, EcoRV, and HindIII according to manufacturer's instructions. Gel electrophoresis, Southern transfers, hybridizations, and autoradiography followed methods in Giannattasio and Spooner (1994).
Polymorphic bands were converted to one (presence) and zero (absence) data. Only clearly visible bands were scored from one enzyme per probe to avoid over-scoring potentially synonymous data from structural mutations (Giannattasio and Spooner, 1994), except for four probes where different probeenzyme combinations gave unambiguously different patterns. The probe-enzyme combination showing the greatest number of bands was chosen for analysis. Principal components analysis of all accessions was performed with a simple matching coefficient similarity matrix and eigenvectors with NTSYSpc, version 1.70 (Rohlf, 1992).

\section{RESULTS Collection of Plant Material}

We collected 21 populations of $S$. kurtzianum from the Provinces of Mendoza and La Rioja (including seven populations from the area of Chilecito, La Rioja Province) and six populations of $S$. $\times$ rechei from the area of Chilecito (Spooner and Clausen, 1993). Young leaves of $S$. $\times$ rechei have enlarged terminal leaflets morphologically similar to mature leaves of S. microdontum (Spooner and Clausen, 1993). Some of our collections were of tubers collected from newly emerging plants of non-flowering material that we initially misidentified as $S$. microdontum, but when grown to maturity later were identified as $S$. $\times$ rechei. Because of this misidentification, we did not collect $S$. microdontum from the imme- 
Table 2. Mean ( \pm SE) and range for percent pollen stainability of all accessions of Solanum kurtzianum, $S$. microdontum, and $S$. $\times$ rechei analyzed for morphological characteristics.

\begin{tabular}{|c|c|c|c|}
\hline \multirow[b]{2}{*}{ Species } & \multirow{2}{*}{$\begin{array}{l}\text { Accessions } \\
\text { examined }\end{array}$} & \multicolumn{2}{|c|}{ Pollen stainability } \\
\hline & & Mean & Range \\
\hline & no. & $\longrightarrow$ & 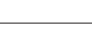 \\
\hline Solanum kurtzianum & 13 & $92.7 \pm 6.6$ & 73-97† \\
\hline S. microdontum & 6 & $85.5 \pm 5.8$ & 77-93 \\
\hline S. $\times$ rechei, $2 n$ & 5 & $25.2 \pm 21.9$ & 4-53 \\
\hline S. $\times$ rechei, $3 n$ & 1 & & 5 \\
\hline
\end{tabular}

$\uparrow$ Spooner and Clausen (1993) report percent pollen stainability for S. kurtzianum as $85 \%$ and ranges for $S$. $\times$ rechei (without mentioning ploidy level) as 0-60\%. Values from Spooner and Clausen (1993) were made from an initial evaluation, and were not those obtained in the present study.

diate area of $S$. $\times$ rechei, the nearest population to Solanum $\times$ rechei being from $160 \mathrm{~km}$ north of the Solanum $\times$ rechei range (Table 1$)$.

Solanum $\times$ rechei is a locally common weed within its restricted range. Eight populations of $S . \times$ rechei are documented from the area, scattered over a distance of $12 \mathrm{~km}$ (Okada and Hawkes, 1978). We collected $S$. × rechei from six of these eight populations. We collected S. kurtzianum at seven populations around the area of $S$. $\times$ rechei, two of them occurring with this species. All populations of both taxa consist of hundreds of individuals, and are easy to locate.

\section{Chromosome Counts}

We obtained diploid $(2 n=24)$ chromosome counts for 12 populations of $S$. kurtzianum, three populations of $S$. microdontum, and five populations of $S . \times$ rechei. One population of $S$. $\times$ rechei was triploid $(2 n=3 x=$ 36). These populations were from the same general sites as those studied by Okada and Hawkes (1978) but were different collections. The chromosome counts were as follows: Solanum kurtzianum, Spooner and Clausen 4505, 4544, 4548, 4549, 4550, 4552, 4568, 4570, 4573, $4575,4576,4577 B$, all $2 n=24$; Solanum microdontum, Spooner and Clausen 4615, 4631, 4632, all $2 n=24$; Solanum $\times$ rechei, Spooner and Clausen 4572, 4574, $4577 A, 4581,4583$, all $2 n=24$; and Solanum $\times$ rechei, Spooner and Clausen 4579, $2 n=36$.

\section{Morphology and Pollen Stainability}

Solanum microdontum and S. kurtzianum showed more than three-fold higher pollen stainability than diploid accessions of $S$. $\times$ rechei; the one triploid population showed even lower stainability (Table 2). Factors 1 and 2 of the PCA for all 22 characters accounted for $48.5 \%$ and $21.3 \%$ of the variation, respectively, or $69.8 \%$ of the total variation. The third component raised the total to $77.6 \%$ but did not change the overall pattern and is not presented. Factor 1 had high loadings (listed in decreasing order) on length of terminal leaflet, number of lateral leaflet pairs, width of stem wing, length of calyx lobe, and color of stem; factor 2 had high loadings on length of first pair of lateral leaflets, width of leaf, width of first pair of lateral leaflets, pollen production, and percent pollen stainability. The PCA using only the

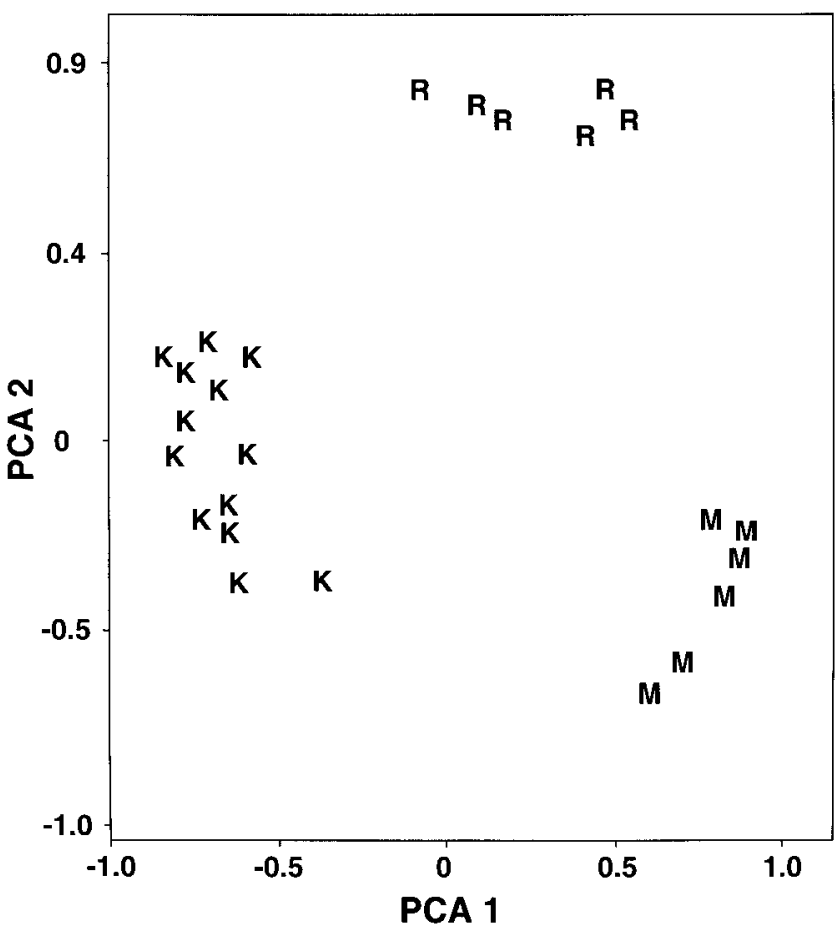

Fig. 2. PCA plot of first two coordinates of entire set of morphological and reproductive characters. $\mathrm{K}=S$. kurtzianum, $\mathrm{R}=S$. $\times$ rechei, $\mathbf{M}=$ S. microdontum.

19 morphological (characters 1-19) produced a biplot similar to Fig. 2 and was not presented. Figure 2 shows $S$. kurtzianum, $S$. microdontum, and $S$. $\times$ rechei form distinctive clusters, all about equally distant from each other with no intermediacy of $S$. $\times$ rechei relative to $S$. kurtzianum and $S$. microdontum.

The character count procedure (Wilson, 1992) rejected the morphological intermediacy of $S . \times$ rechei. Only eight of 19 morphological characters were intermediate (Table 3 ). Fifteen of the 19 characters would need to be intermediate for morphological intermediacy to be accepted at $P=0.05$ (Zar, 1984). Eight of the nonintermediate characters were transgressive beyond $S$. kurtzianum, two characters were transgressive beyond both $S$. kurtzianum and $S$. microdontum (character 15 and 18), and one character was transgressive beyond S. microdontum (character 2).

\section{Nuclear RFLPs}

We scored 80 polymorphic bands from the 19 probeenzyme combinations. Many of the probe-enzyme combinations showed similar patterns indicating structural mutations, rather than site mutations, a typical pattern for some low-copy nuclear RFLP studies (Wang and Tanksley, 1989). Data from four of the probes (P60, P135, P279, P398) were scored with bands from a second endonuclease because they had no apparent redundancy of band pattern to the other scored endonuclease. Of the 15 probes scored in our study, one exhibited complete additivity of bands in $S$. $\times$ rechei possessed by $S$. kurtzianum and $S$. microdontum, and an additional three exhibited complete additivity except for $S$. $\times$ rechei Spooner and Clausen 4579 (Fig. 3), the sole triploid 
Table 3. Taxon means for 22 morphological and reproductive characters of three wild potato species, and test for intermediacy of S. $\times$ rechei.

\begin{tabular}{|c|c|c|c|c|c|}
\hline Character & $\begin{array}{c}\text { Character } \\
\text { number }\end{array}$ & S. microdontum & S. $\times$ rechei & S. kurtzianum & Intermediacy $\dagger$ \\
\hline Plant height, cm & 1 & 56.7 & 34.5 & 20.2 & I \\
\hline Stem color, 1-4 & 2 & 2.3 & 2.8 & 1.8 & $\mathbf{M}$ \\
\hline Stem wing width, $\mathrm{mm}$ & 3 & 2.3 & 1.7 & 0.7 & I \\
\hline Leaf length, cm & 4 & 14.0 & 19.7 & 15.1 & $\mathbf{K}$ \\
\hline Leaf width, cm & 5 & 9.2 & 12.5 & 10.2 & $\mathbf{K}$ \\
\hline No. of lateral leaflet pairs & 6 & 1.0 & 3.7 & 4.2 & I \\
\hline Terminal leaflet length, cm & 7 & 11.5 & 8.3 & 6.0 & I \\
\hline Terminal leaflet width, cm & 8 & 7.7 & 4.9 & 3.3 & I \\
\hline Distal most lateral leaflet length, cm & 9 & 3.1 & 6.9 & 5.1 & $\mathbf{K}$ \\
\hline Distal most lateral leaflet width, cm & 10 & 1.7 & 3.5 & 2.6 & $\mathbf{K}$ \\
\hline Second distal most lateral leaflet length, cm & 11 & 0.6 & 4.8 & 4.9 & I \\
\hline Second distal most lateral leaflet width, $\mathrm{cm}$ & 12 & 0.3 & 2.7 & 2.6 & $\mathbf{K}$ \\
\hline No. of interjected leaflets & 13 & 0.0 & 8.2 & 6.5 & $\mathbf{K}$ \\
\hline Pedicel articulation position, 1-3 & 14 & 1.0 & 1.7 & 3.0 & I \\
\hline Calyx length, $\mathbf{m m}$ & 15 & 0.6 & 0.7 & 0.6 & M, K \\
\hline Corolla adaxial surface color, 1-4 & 16 & 10.0 & 7.3 & 5.8 & I \\
\hline Corolla radius ratio & 17 & 6.5 & 4.6 & 5.5 & $\mathbf{K}$ \\
\hline Anther length, mm & 18 & 2.0 & 0.5 & 2.0 & $\mathbf{M}, \mathbf{K}$ \\
\hline Style exsertion, mm & 19 & 3.0 & 3.9 & 3.7 & $\mathbf{K}$ \\
\hline Anther formation, 0-2 & 20 & 1.8 & 1.5 & 1.3 & \\
\hline Pollen production, 1-2 & 21 & 2.0 & 1.0 & 2.0 & \\
\hline Pollen stainability, \% & 22 & 85.6 & 21.8 & 89.0 & \\
\hline
\end{tabular}

$\dagger \mathbf{I}=S . \times$ rechei intermediate between $S$. kurtzianum and $S$. microdontum, $\mathbf{M}=S . \times$ rechei transgressive beyond $\mathbf{S}$. microdontum, $\mathbf{K}=S$. $\times$ rechei transgressive beyond $S$. kurtzianum. Reproductive characters 20-22 were not assessed for intermediacy in the "character count procedure" of Wilson (1992).

population examined. Other probe-enzyme combinations exhibited shared bands between some accessions of $S . \times$ rechei and either $S$. kurtzianum or S. microdontum. There also were bands unique to each species.

Figure 4 presents the results of PCA axes 1 and 2 of the nRFLP data. The first and second components account for $54.3 \%$ and $17.0 \%$, and separated $S$. kurtzianum from $S$. microdontum, with $S . \times$ rechei in an intermediate position. Some bands present in S. microdontum and $S$. kurtzianum that showed additivity in $S$. $\times$ rechei were present in other species. The other wild potato species formed separate clusters, but with $S$. commersonii closest to $S$. microdontum. Solanum commersonii is a lowland species (sea-level to $400 \mathrm{~m}$ ) growing in northeastern Argentina and adjacent Brazil, Paraguay and Uruguay, $500 \mathrm{~km}$ east of $S$. $\times$ rechei (Hawkes and Hjerting, 1969). The results separate $S$. palustre far from other taxa, concordant with data based on morphology (Hawkes, 1990), crossability (Ramanna and Hermsen, 1981; Matsubayashi, 1991), nDNA (Debener et al., 1990), and chloroplast DNA (Hosaka et al., 1984; Spooner et al., 1993).

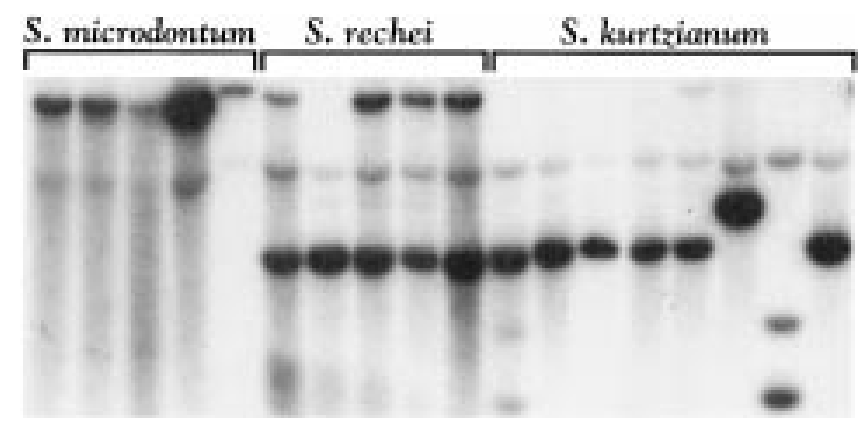

Fig. 3. Autoradiogram of probe/enzyme combination P398-DraI, showing additivity in four of the five accessions of $S$. $\times$ rechei for bands from $S$. microdontum and S. kurtzianum.

\section{DISCUSSION}

The distributional, reproductive, and nRFLP data all support the hybrid origin of $S$. $\times$ rechei from $S$. kurtzianum and $S$. microdontum. Solanum $\times$ rechei is located at a marginal overlap zone of both parents. The species is not a chance hybrid located in a restricted site. It occurs in both regularly artificially disturbed areas such

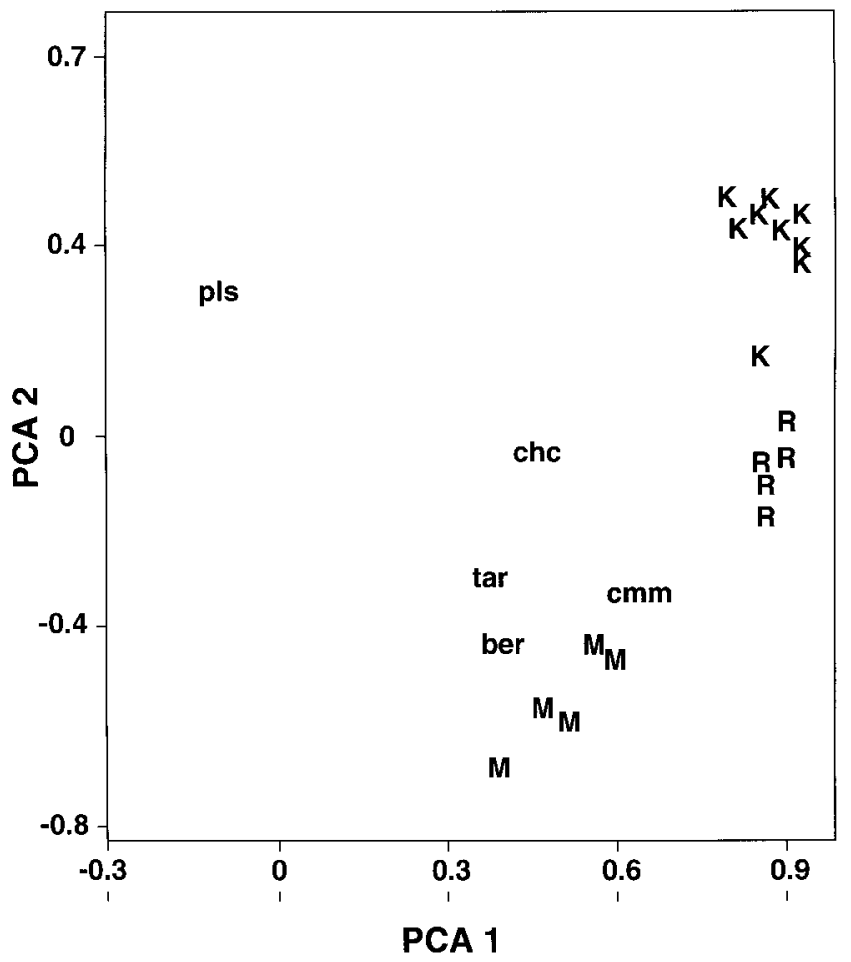

Fig. 4. PCA plot of first two coordinates of $n R F L P$ data set. $K=$ S. kurtzianum, $\mathbf{R}=S$. $\times$ rechei, $\mathbf{M}=S$. microdontum, ber $=$ S. berthaultii, chc $=S$. chacoense, $\mathbf{c m m}=S$. commersonii, pls $=$ S. palustre, tar $=$ S. tarijense. 
as under orchards, ditches, and roadsides, as well as along naturally disturbed areas such as streamsides. The reduced pollen stainability of $S$. $\times$ rechei is concordant with prior observations of Okada and Hawkes (1978) and with hybridization between divergent species. Solanum $\times$ rechei shows additive nRFLP profiles of its two putative parental species, S. kurtzianum and $S$. microdontum. This support must be tempered with the observation that some bands possessed in S. microdontum and $S$. kurtzianum that showed additivity in $S$. $\times$ rechei were not always unique to these putative parental species, but were also possessed by the other species examined. Also $S . \times$ rechei showed some unique bands. Unique RFLP bands have been documented in the $\mathrm{F}_{6}$ generation of synthetic artificial polyploids in Brassica (Song et al., 1995).

It is unresolved if diploid or triploid populations of S. microdontum, or both, were the parents. Okada and Hawkes (1978) hypothesized that triploid populations of $S$. microdontum were the maternal parents of this hybrid event(s), but this was stimulated by the collection of triploid S. microdontum from the area, and it is possible diploids were undetected. We did not locate populations of S. microdontum from the area of hybridization (Spooner and Clausen, 1993), but did locate the species $160 \mathrm{~km}$ farther north. Nuclear RFLP support for the hybrid origin of $S$. $\times$ rechei, therefore, must assume that the S. microdontum bands we examined from other populations are representative of the parental populations (diploid or triploid). It also assumes that other possible parents with other bands showing additivity in $S$. $\times$ rechei are not likely candidates in its hybrid origin, because they do not grow in the immediate area of S. $\times$ rechei.

An alternative explanation for the molecular intermediacy of $S$. $\times$ rechei is the retention of plesiomorphic (ancestral) characters, such that $S$. kurtzianum and $S$. microdontum were derived from $S$. $\times$ rechei (Rieseberg and Ellstrand, 1993). Although possible, the very restricted distribution of $S . \times$ rechei and particularly its lowered male fertility strongly suggests that it is a locally derived hybrid.

The morphological results of the multivariate analysis (PCA) and the univariate "character count procedure" of Wilson (1992) do not show $S$. × rechei to be strictly intermediate. Additive morphology, however, is not always associated with hybridity. Rather, hybrids often show a mosaic of intermediate, parental, transgressive, or novel morphological characters (McDade, 1990; Rieseberg and Ellstrand, 1993); all but novel characters were demonstrated here.

To date, only $S$. $\times$ rechei and two other diploid wild potato species of putative hybrid origins have been reinvestigated with molecular data. These are (i) Solanum raphanifolium Cárdenas and Hawkes, hypothesized by Ugent (1970) to involve $S$. canasense Hawkes and $S$. megistacrolobum Bitter, a hypothesis later refuted by chloroplast DNA and nuclear ribosomal DNA data (Spooner et al., 1991) and by single- to low-copy nRFLP data (Giannattasio and Spooner, 1994); and (ii) Solanum chacoense mountain populations, hypothesized by
Hawkes (1962) to be of introgressive origin between lowland populations of $S$. chacoense and S. microdontum, a hypothesis later refuted by morphological data, single- to low-copy nRFLP data, and RAPD data (Miller and Spooner, 1996).

Solanum raphanifolium and $S$. $\times$ rechei were both suggested to have hybrid origins because of relatively narrow distributions in the overlap zone of their putative parents. Initial evidence of hybrid origin was suggestive. The putative hybrids are both intermediate in at least some characters between their parents, and are weedy plants that are restricted to the overlap zone of their putative parents. While some putative hybrid species in sect. Petota share this morphological and distributional pattern (e.g., S. doddsii Correll, S. ruiz-lealii Brücher), others are widely distributed throughout the sympatric zone of their putative parents (e.g., S. sucrense Hawkes, S. tuberosum L. subsp. andigena Hawkes). Other putative hybrid taxa in sect. Petota need to be investigated more rigorously to document the occurrence of hybridization and to understand the relative importance of hybridization in the process of speciation in Solanum sect. Petota. Our data suggest that some wild potato species may be of hybrid origin, and help to better explain the taxonomic confusion in wild potatoes.

\section{ACKNOWLEDGMENTS}

Names are necessary to report factually and available data; however, the USDA neither guarantees nor warrants the standard of the product, and the use of the name by USDA implies no approval of the product to the exclusion of others that may also be suitable. We thank INTA, Balcarce, the Facultad de Ciencias Agrarias de Balcarce, and the Consejo Nacional de Investigaciones Cientificas y Técnicas (CONICET) for grants to conduct research; Brian Karas and Joseph T. Miller for technical assistance; and Harvey Ballard for review.

\section{REFERENCES}

Bamberg, J., M. Martin, J. Schartner, and D.M. Spooner. 1996. Inventory of tuber-bearing Solanum species. Potato Introd. Stn., NRSP6, Sturgeon Bay, WI.

Bamberg, J., and D.M. Spooner. 1994. The United States Potato Introduction Herbarium. Taxon 43:489-496.

Brücher, H.E. 1989. Refutation of recent creations of microspecies and hybrid taxa in Argentinian Solanum (sect. Petota). Phytologia 67:220-226.

Child, A. 1990. A synopsis of Solanum subgenus Potatoe (G. Don) (D’Arcy) (Tuberarium (Dun) Bitter (s. 1.)). Feddes Repert. 101:209-235.

Contreras-M., A, and D.M. Spooner. In press. Revision of Solanum section Etuberosum. In M. Nee et al. (ed.) Solanaceae IV: taxonomy, chemistry, evolution. Royal Botanic Gardens, Kew, England.

Cribb, P.J., and J.G. Hawkes. 1986. Experimental evidence for the origin of Solanum tuberosum subspecies andigena. p. 383-404 In W.G. D'Arcy (ed.) Solanaceae: Biology and systematics. Columbia Univ. Press, New York.

Debener, T., F. Salamini, and C. Gebhardt. 1990. Phylogeny of wild and cultivated Solanum species based on nuclear restriction fragment length polymorphisms (RFLPs). Theor. Appl. Genet. 79:360-368.

Giannattasio, R.B., and D.M. Spooner. 1994. A reexamination of species boundaries and hypotheses of hybridization concerning Solanum megistacrolobum and S. toralapanum (Solanum sect. Petota, series Megistacroloba): molecular data. Syst. Bot. 19:89-105 Feinberg, A.P., and B. Vogelstein. 1984. Addendum. A technique for 
radiolabelling DNA restriction endonuclease fragments to high specific activity. Anal. Biochem. 137:266-267.

Hanneman, R.E., Jr. 1994. Assignment of Endosperm Balance Numbers to the tuber-bearing Solanums and their close non-tuberbearing relatives. Euphytica 74:19-25.

Hawkes, J.G. 1962. Introgression in certain wild potato species. Euphytica 11:26-35.

Hawkes, J.G. 1963. A revision of the tuber-bearing Solanums. II. Scott. Plant Breed. Stn. Rec. 1963:76-181.

Hawkes, J.G. 1978. Biosystematics of the potato. p. 15-69. In P.M. Harris (ed.). The potato crop: The scientific basis for improvement Chapman and Hall, London.

Hawkes, J.G. 1990. The potato: Evolution, biodiversity and genetic resources. Smithsonian Institution Press, Washington, DC.

Hawkes, J.G., and J.P. Hjerting. 1969. The potatoes of Argentina, Brazil, Paraguay and Uruguay: A biosystematic study. Oxford Univ. Press, Oxford, England.

Hawkes, J.G., and J.P. Hjerting. 1989. The potatoes of Bolivia: their breeding value and evolutionary relationships. Oxford Univ. Press, Oxford, England.

Holmgren, P.K., N.H. Holmgren, and L.C. Barnett. 1990. Index Herbariorum part I: the herbaria of the world. New York Botanical Garden, New York.

Hosaka, K., Y. Ogihara, M. Matsubayashi, and K. Ttsunewaki. 1984. Phylogenetic relationship between the tuberous Solanum species as revealed by restriction endonuclease analysis of chloroplast DNA. Japan. J. Genet. 59:349-369.

Hosaka, K., and D.M. Spooner 1992. RFLP analysis of the wild potato species, Solanum acaule Bitter (Solanum sect. Petota). Theor. Appl. Genet. 84:851-858.

Johnston, S.A., and R.E. Hanneman, Jr. 1980. Support of the Endosperm Balance Number hypothesis utilizing some tuber-bearing Solanum species. Am. Potato J. 57:7-14.

Johnston, S.A., and R.E. Hanneman, Jr. 1982. Manipulations of Endosperm Balance Number to overcome crossing barriers between diploid Solanum species. Science 217:446-448.

Matsubayashi, M. 1991. Phylogenetic relationships in the potato and its related species. p. 93-118. In T. Tsuchiya and P.K. Gupta (ed.) Chromosome engineering in plants: Genetics, breeding, evolution, part B. Elsevier, Amsterdam.

McDade, L. 1990. Hybrids and phylogenetic systematics I. Patterns of character expression in hybrids and their implications for cladistic analysis. Evolution 44:1685-1700.

Miller, J.T., and D.M. Spooner. 1996. Introgression of Solanum chacoense (Solanum sect. Petota) upland populations reexamined. Syst. Bot. 21:461-475.

Ochoa, C.M. 1990. The potatoes of South America: Bolivia. Cambridge Univ. Press, Cambridge, England.

Okada, K.A. 1974. Colección de Solanum tuberiferos de Argentina. Lista de semillas No. 3, Diciembre, 1974. Instituto Nacional de Tecnología Agropecuaria, Balcarce, Argentina.

Okada, K.A. 1981. High frequency of triploids of Solanum microdontum subsp. gigantophyllum on the western mountain ranges of Provinces La Rioja and Catamarca, Argentina. Euphytica 31: $817-835$.
Okada, K.A., and A.M. Clausen. 1982. Natural hybridization between Solanum acaule Bitter and S. infundibuliforme Philippi in the Province of Jujuy, Argentina. Euphytica 34:219-231.

Okada, K., and J. Hawkes. 1978. Solanum $\times$ rechei, especie silvestre de papas de origen hibrido de la Sierra de Famatina (Provincia de la Rioja, Argentina). Kurtziana 11:55-74.

Ramanna, M.S., and J.G.H. Hermsen. 1981. Structural hybridity in the series Etuberosa of the genus Solanum and its bearing on crossabiliy. Euphytica 30:15-31.

Rickeman, V.S., and S.L. Desborough. 1978. Elucidation of the evolution and taxonomy of cultivated potatoes with electrophoresis. Theor. Appl. Genet. 52:217-220.

Rieseberg, L.H., and N.C. Ellstrand. 1993. What can molecular and morphological markers tell us about plant hybridization? Crit. Rev. Plant Sci. 12:213-241.

Rohlf, F.J. 1992. NTSYS-pc, numerical taxonomy and multivariate system. Exeter Publishing, Ltd., New York.

Sharma, A.K., and A. Sharma. Chromosome techniques. Theory and practice. Butterworths, London.

Smith, J.F., K.J. Sytsma, R.L. Shoemaker, and R.L. Smith. 1991. A qualitative comparison of total cellular DNA extraction protocols. Phytochem. Bull. 23:2-9.

Song, K., P. Liu, and T.C. Osborn. 1995. Rapid genome change in synthetic polyploids of Brassica and its implications for polyploid evolution. Proc. Natl. Acad. Sci. (USA) 92:7719-7723.

Spooner, D.M., G.J. Anderson, and R.K. Jansen. 1993. Chloroplast DNA evidence for the interrelationships of tomatoes, potatoes, and pepinos (Solanaceae). Am. J. Bot. 80:676-688.

Spooner, D.M., and A. Clausen. 1993. Wild potato (Solanum sect. Petota) germplasm collecting expedition to Argentina in 1990, and status of Argentinian potato germplasm resources. Potato Res. 36:3-12.

Spooner, D.M., K.J. Sytsma, and J.F. Smith. 1991. A molecular reexamination of diploid hybrid speciation of Solanum raphanifolium. Evolution 45:757-764.

Spooner, D.M., and R.G. Van den Berg. 1992. Species limits and hypotheses of hybridization of Solanum berthaultii Hawkes and S. tarijense Hawkes: morphological data. Taxon 41:685-700.

Tanksley, S.D., M.W. Ganal, J.P. Prince, M.C. de Vicente, M.W. Bonerbale, P. Broun, T.M. Fulton, J.J. Giovannoni, S. Grandillo, G.B. Martin, R. Messeguer, J.C. Miller, L. Miller, A.H. Patterson, O. Pineda, M.S. Röder, R.A. Wing, W. Wu, and N.D. Young. 1992. High density molecular linkage maps of the tomato and potato genomes. Genetics 132:1141-1160.

Thébaud, C., and R.J. Abbott. 1995. Characterization of invasive Conyza species (Asteraceae) in Europe: quantitative trait and isozyme analysis. Am. J. Bot. 82:360-368.

Ugent, D. 1970. The potato. Science 170:1161-1166.

Wang, Z.Y., and S.D. Tanksley. 1989. Restriction fragment length polymorphism in Oryza sativa L. Genome 32:1113-1118.

Wilson, P. 1992. On inferring hybridity from morphological intermediacy. Taxon 41:11-23.

Zar, J.H. 1984. Biostatistical analysis. Prentice Hall, Englewood Cliffs, NJ 